\title{
Climate Justice Begins at Home: Conceptual, Pragmatic and Transformative Approaches to Climate Justice in Scotland
}

\begin{abstract}
In March 2012 the Scottish Parliament unanimously passed a motion "strongly endors[ing] the opportunity for Scotland to champion climate justice". To date, discussions around climate justice within Scottish policy have largely focussed on international dimensions. Questions remain as to what climate justice means at home in Scotland. This article aims to engage with such questions. It begins with an overview of the theoretical underpinnings of climate justice discourses and discusses the various ways that climate justice is framed and understood. We then introduce a categorisation of three broad approaches to climate justice which are being seen globally: conceptual, pragmatic and transformative. We discuss how climate justice has been pursued in practice to illustrate the different forms that can occur under a climate justice banner, and the implications of different understandings of the concept. Using the human rights based approach to climate change as an illustration of the malleable nature of climate justice, we categorise and critique the dominant approach to climate justice used in Scotland. We find that climate justice is a label which can be applied to a range of practices, with differing results. It is hoped that this article encourages further reflection and debate on the particular flavour of climate justice which has been chosen in Scotland and its implications.
\end{abstract}

Key Words: climate justice, environmental justice, human rights and climate change, human rights based approach. 


\section{Climate Justice Begins at Home: Conceptual, Pragmatic and Transformative Approaches to Climate Justice in Scotland}

The Scottish Government clearly recognises Scotland's international responsibilities to help to secure climate justice for some of the poorest and most vulnerable people on the planet. That is entirely in keeping with Scotland's sense of the common weal. The establishment of a climate justice fund is a natural extension of that intrinsic Scottish characteristic...

Annabelle Ewing MSP (Scottish Parliamentary Debate on Climate Justice, $1^{\text {st }}$ March 2012)

The concept of climate justice-or, more appropriately, climate injustice-is not difficult to comprehend. By adhering to a flawed and often brutally uncompromising economic system, the west has grown wealthy at the expense of people in the developing world by exploiting their human and natural resources to satisfy our demand for material goods.

Neil Findlay MSP (ibid)

\section{Introduction}

In March 2012 the Scottish Parliament unanimously passed a motion "strongly endors[ing] the opportunity for Scotland to champion climate justice". This has been described as historic with Scotland said to be the first country to debate such a motion (MRFCJ, 2012) and reflects broader vocal commitments of the Scottish Government for Scotland to be a world leader in addressing climate change (e.g. Scottish Government, 2009).

The passing of such a motion may be considered a bold move given that climate justice typically sits outside mainstream policy-making and can be regarded as challenging existing capitalist and modernist systems (Aitken, 2012). Yet recent years have witnessed the emergence of many different forms or understandings of climate justice with varying implications for policy and action. This enables some flexibility in how climate justice is pursued and means that the 'boldness' of such a commitment may be less than first appears. It also gives rise to debate and disputes over the ways in which the term is used, or misused. For example, for some climate justice calls for transformative change to renounce capitalist systems 
of production and the pursuit of profits, requiring a move towards systems which prioritise equality and equity, stressing the need to live within the ecological limits of the planet (e.g. http://climatejusticecampaign.org). Whereas for others climate justice can be pursued through existing economic frameworks and policy mechanisms, such as emissions trading schemes (Posner and Weisbach, 2010). As will be discussed, the Scottish Government has committed to a 'human rights based approach' to climate change as a means of securing climate justice (SHRC, 2013). This can imply various different forms of climate justice which may not always realise their transformative potential, and demonstrates the variety of ways in which climate justice can be framed and interpreted, with significant implications for which actions or policies may be pursued and/or prioritised.

To date much of the literature and policy discussions have focussed on climate justice's international dimensions, calling attention to global injustice relating to the causes and impacts of climate change. It is frequently noted that countries of the global South have contributed the least to causing climate change (i.e. in greenhouse gas emissions) but are expected to be the most severely affected by the impacts of climate change. This leads to recognition of 'common but differentiated responsibilities' for tackling climate change at the international level (UNFCCC, 1992: Article 3).

Climate justice will be crucial to the success of the hugely important international climate talks to be held in Paris in December 2015, but its interpretation (and significance) at a domestic level is less appreciated. Inequalities such as those well documented at the international scale, also exist within countries. For example it is disadvantaged groups within particular countries who are likely to experience most severely the negative impacts of climate change. Within Scotland such groups may include, among others, those on low incomes, those living in remote rural areas, the elderly and those with long-term health conditions. For instance, low income groups may lack the resources to prepare for, respond to and recover from climate related events such as heatwaves or flooding (Preston et al, 2014: 25). Moreover, injustice is not solely associated with the impacts of climate change but also the costs of mitigation or adaptation strategies. Despite climate policy being largely depoliticised, domestic decarbonisation is not a purely mechanical, technical exercise; questions of justice are fundamental to the transition to a low carbon society (Hodson and Marvin, 2013). For example, low income households in the UK face a triple climate injustice; they emit the least (the poorest emitting three times less than the wealthiest); they pay a disproportionately higher amount towards the cost of climate policies; and they tend to benefit the least (e.g. financial support for installing domestic energy 
efficiency improvements - Preston et al, 2013a). Mitigation costs are being passed on by energy companies to consumers, resulting in increased energy bills; one of the key drivers of fuel poverty. The implications of energy decarbonisation for the number of Scottish households living in cold, damp homes is perhaps the most visible of the looming climate injustices faced at home (CCC, 2014: 45-52). Climate justice is equally salient in the domestic context as it is internationally.

As in the broader climate justice debate, so far, discussions around climate justice within Scottish policy have been internationally focussed. The motion passed in the Scottish Parliament in 2012 stated that climate justice represented an opportunity to place "human rights at the heart of global development" and strengthen "Scotland's support for developing countries on climate change as part of Scotland's international profile". This international focus is explicit in the aims and activities of the Climate Justice Fund which was created following the passing of the motion. This was launched in 2012 with a three million pound budget, aiming to "address the needs of climate vulnerable people, particularly recognising the disproportionate effect the impact of climate change can have on the poor, and women and children in developing countries" (Scottish Government, 2014). In 2014 a second round of the fund was launched with a further three million pounds funding. To date the fund has focussed on water-related adaptation projects in Africa. Adopting this international focus positions climate justice as a component of Scotland's international development strategy and as part of the Government's efforts at foregrounding Scotland on the international stage. Work undertaken in this area is clearly valuable and worthwhile, however questions remain as to whether the resources allocated to the fund represent anything more than a tokenistic gesture when measured against the harm related to Scotland's historic emissions, and what climate justice means at home in Scotland.

This article aims to engage with these questions. It begins with an overview of the theoretical underpinnings of climate justice discourses and discusses the various ways that climate justice is framed and understood. We then introduce a categorisation of three broad approaches to climate justice which are being seen globally: conceptual, pragmatic and transformative. We discuss how climate justice has been pursued in practice in Scotland, in order to illustrate the different forms that can occur under a climate justice banner, and the implications of different understandings of the concept. Using the human rights based approach to climate change to illustrate the malleable nature of climate justice, we categorise and critique the dominant Scottish approach to climate justice. 


\section{Climate Justice Background}

Theories of social justice are complex and contested with understandings of social justice varying "greatly according to historical, geographical and cultural context" (Preston et al, 2014: 13). However, climate change has brought new dimensions of complexity: whilst historically, the responsibilities, geographical and temporal relationships and identifiable harms between different actors in moral problems were well-defined and clear, this has been challenged by climate change's diffuse and intergenerational nature (Singer, 2010; Jamieson, 2010). Increasing scientific understanding has revealed that there are ways of harming others by actions which lack intention, and are geographically and temporally remote (van der Horst, 2014).

The finite ability of the climate to cope with anthropogenic greenhouse gas emissions demands new thought on how rights to release emissions are allocated, and where responsibility lies for the harms caused by emissions. The emergence of climate justice is a response to the need for a novel approach to justice in light of climate change's particular challenges.

\section{A. Climate Change Injustices}

Climate justice captures the understanding that justice and climate change are intimately linked. The main connections concern the inequitable distribution of the physical impacts of climate change, historic responsibility for the problem and the ambition, and the nature of the mitigation and adaptation responses (particularly how these are paid for and distributed).

The intensity and nature of the physical impacts of climate change are unevenly spread, differing amongst and within countries. This inequity is a product of the nature of the physical change, the extent to which societies depend on the natural resources being affected (e.g. agrarian societies face large risks from changes to temperature and precipitation levels) and capacity for handling change. Exposure to the physical impacts of climate change is something of a 'geographical lottery'. For example, low-lying coastal nations and atolls such as Bangladesh and Tuvalu (or closer to home - Benbecula) stand to lose considerable areas of land mass and may even entirely disappear due to rising ocean levels; whereas others like the UK may experience some benefits from increased temperatures such as longer growing seasons leading to improving crop yields (UK Government, 2012). However, even these benefits are 
themselves mixed with uncertainty with higher UK temperatures being coupled with more frequent adverse weather conditions bringing flooding events (Kohn, 2010). Climate change will exacerbate existing socioeconomic inequalities - as the chair of the IPCC has explained; "it is the poorest of the poor in the world, and this includes poor people in prosperous societies, who are going to be the worst hit" (BBC News, 2007). Climate change impacts are also gendered - gender inequalities can exacerbate vulnerabilities to natural hazards - fuelled by climate change (Burnham et al, 2013). Women (particularly in the global South) are seen as more vulnerable to climate change due to their relatively limited access to resources and resulting poverty, and tend to die in greater numbers during and immediately after natural disasters due to the their lower socio-economic status (Terry, 2009).

The sense of injustice evoked by climate change is felt most keenly due to the disjuncture between those responsible for causing climate change, and those who will feel its impacts most strongly: "the bitter effects of climate change will hit first and most powerfully the countries and people who did least to cause it" (Sachs and Santarius, 2007: 53). Historic greenhouse gas emissions contributions differ vastly across the world. Countries which industrialised earlier tend to have emitted a much larger share of the greenhouse gases currently in the atmosphere than less developed countries; and within industrialised nations there are disparities in greenhouse gas emissions, with poorer citizens of industrialised nations having far lower per capita emissions than their richer counterparts (Preston et al, 2013a). These disparities raise difficult questions of compensatory and intergenerational justice - do industrialised nations owe a 'climate debt' to the rest of the world? Greenhouse gases have long residence times in the atmosphere, and 'climate inertia' means that the effects of emissions may not be realised for many years after they were emitted - who should be made to account for the emissions of those who are no longer alive? The inheritance of responsibilities for emissions poses problems; are these collective, area-based responsibilities to be shared between all residents of particular high-emitting countries, or more individualised, kin-based responsibilities handed down to descendants of high emitting individuals or groups within society? How can we - or should we - account for variations in responsibility within countries?

There are also justice issues associated with mitigation and adaptation. As a method of mitigating fossil-fuel emissions, energy 'decarbonisation' is being pursued through a combination of technologies: end-use energy efficiency, renewables, nuclear and carbon capture and storage. Investment in these expensive technologies raises energy prices; spending on energy often comprises a higher proportion of household spending in lower income homes, 
meaning that such energy price increases tend to be socially regressive (Gough, 2011). Low income households that use electricity to heat their homes are likely to be hardest hit by the costs of energy policies in the future as the majority of these costs are placed on electricity to fund the decarbonisation of this energy vector (Preston et al, 2013b). Less developed countries may lack the resources and capacity to adapt to climate change, leaving them more exposed. Climate justice also questions their 'right to development'- fossil fuel-driven economic growth must be avoided in a limited climatic space.

\section{B. Environmental Justice Roots}

The climate justice movement has a number of roots but there are clear connections with the environmental justice movement which has focussed on how environmental 'goods' and 'bads' are distributed (e.g. Evans, 2010). The movement started in the U.S., examining the unfair distribution of environmental 'bads' (e.g. waste facilities and incinerators) in areas largely populated by low income groups and black and ethnic minority communities (e.g. Bullard, 1993). In the U.S. environmental justice grew out of the 'environmental racism' movement and the civil rights struggle of the mid to late $20^{\text {th }}$ century (Benford, 2005). Following a process of 'globalisation from below', the environmental justice frame has since been adopted by a range of civil society actors across the globe (Schlosberg, 2013; Walker, 2009).

Environmental justice's success in the UK has been more muted - emerging first in the late $1990 \mathrm{~s}$ as a response to socioeconomic inequalities in exposure to industrial pollution (Agyeman, 2002). Friends of the Earth's 1999 'Pollution Injustice' study suggested a relationship between the location of polluting industrial sites and low income communities in England and Wales, catalysing the UK environmental justice movement. Friends of the Earth (and their Scottish counterpart) adopted environmental justice campaigns, and a variety of official responses were seen - with environmental regulators across the UK commissioning studies on environmental inequalities. A political movement more attuned to the philosophy of the Left, environmental justice's "susceptibility to political neglect in accordance with executive winds of change" (Pedersen, 2014: 87) has seen its goals receive less attention under the Coalition Government.

Environmental justice has gained some traction in Scottish public policy (Scandrett, 2007). Jack McConnell's Dynamic Earth speech in 2002 established environmental justice as a policy objective. The commissioned research that followed convinced politicians and senior civil 
servants that public participation in the decision-making process and a focus on redistributing environmental 'goods' and 'bads' would lead to better environmental outcomes that were inherently more just. Scottish Ministers gave guidance to the Scottish Environmental Protection Agency to address environmental justice issues 'insofar as its functions permitted'; mainly licencing and enforcement.

\section{The Climate Justice Movement}

Environmental justice activists have been instrumental in the emergence and mobilisation of the climate justice movement (MRFCJ, 2013). Other activist groups who have played important roles have come from global justice and anti-capitalist perspectives. These groups have previously led mass demonstrations and protests, for example at the summits of the G7/8, International Monetary Fund, World Bank and World Social Forum (Mueller \& Bullard, 2012).

Within the academic literature climate justice is said to have first been referred to by Weiss in 1989 and the term began to be used by activists in the late 1990's (MRFCJ, 2013). However, it was at the turn of the century that the climate justice movement gained momentum. The first international climate justice summit was held in 2000 in The Hague in parallel with the sixth United Nations Framework Convention on Climate Change (UNFCCC) Conference of the Parties negotiations (Karliner, 2000). Following this in 2001, the World Conference Against Racism in Durban, South Africa provided a forum for discussions around environmental justice which led to a realisation of the global relevance of the subject matter (Bullard, 2000) and facilitated international networking and exchange of experiences and ideas (MRFCJ, 2013). In June 2002, environmental organisations from around the world met in Bali to discuss climate justice, resulting in the 'Bali Principles of Climate Justice' and the creation of the Climate Action Network (CAN).

CAN was the main body representing environmental civil society views on UNFCCC processes until 2007 when - at COP 13 in Bali - its more radical members broke away to form Climate Justice Now! (CJN!) (MRFCJ, 2013). Describing itself as 'a network of organisations and movements from across the globe committed to the fight for social, ecological and gender justice', CJN! produced its own set of climate justice principles (CJN!, 2009). CJN! have adopted a more radical approach than CAN who are viewed to take a more market-oriented position (MRFCJ, 2013). 
From 2007 onwards climate justice has continued to gather momentum and is referred to with increasing frequency. For example, at subsequent UNFCCC COP meetings climate justice activists from around the world have mobilised in highly organised demonstrations and conferences and increasingly more mainstream NGOs (such as Greenpeace) have joined the movement (MRFCJ, 2013). However, this movement largely has an international focus and discussions of the relevance of climate justice in domestic contexts tends to be located in countries of the global South.

\section{Why Climate Justice?}

Climate change policy is dominated by the natural sciences and neoliberal economics. The market-driven, 'climate capitalist' nature (Newell and Paterson, 2010) of much climate policy constrains the potential for a transformative low carbon transition. Swyngedouw argues that climate change has been de-politicised through the emergence of a 'fragile consensus' which has emerged both in relation to "the "nature" of the problem and the arrays of managerial and institutional technologies to mitigate the most dramatic consequences" (2010: 215). The strategies favoured reflect modernist goals of economic growth and development and limit opportunities for more transformative policy responses (Aitken, 2012). Efficiency and economic growth are key in market mechanisms such as the EU Emissions Trading Scheme, leaving little space for discussing the historic and political roots of the problem.

Re-framing climate change as a global justice concern re-politicises the issue (Liverman, 2009), questioning the distribution of political power by asking who wins and who loses in terms of access and rights to the climate, and who owns the atmosphere (Chatterton et al, 2012). This creates the potential for future approaches which take account of the history of where the climate problem came from and the adoption of fairer solutions and outcomes. However, a justice frame brings problems too; a focus on fairness may lack the pragmatism needed to make effective international climate agreements (Posner and Weisbach, 2010), and justice is a highly contested 'dialectic' notion (Low and Gleeson, 1998).

Within the notion of climate justice lie four interconnected tenets of justice: distributive, procedural, recognitional and capabilities. Although conceptually distinct, they are closely connected and cannot be considered in isolation (Schlosberg, 2007: 28). Distributional justice draws attention to the distribution of the harms and benefits of climate change, the distribution of and responsibility for the payment of the mitigation and adaptation responses to climate 
change, and the level of emissions to be globally agreed as a 'safe' threshold. Procedural justice recognises that distributional injustices often occur due to the underlying unfair processes which create them - and requires that decision-making must be fair and inclusive to produce just outcomes. In relation to energy and climate infrastructure decisions related to decarbonisation in the UK, Lee et al have noted the minimal legal participatory requirements risk a "self-perpetuating vicious circle" (2013: 60), whereby the public has little opportunity to influence decision-making, resulting in less public engagement and policy-makers resorting to tick-box bureaucratic exercises. Recognitional justice acknowledges that a just society can only be achieved through accepting and according respect to distinct cultures and identities - and aims to secure the dignity of individuals in pluralistic societies (Honneth, 2004). Recognitional justice is critical to appreciate, and challenge the lack of recognition of the particular harms climate change causes to cultural practices across the globe. For example, changes to species distribution, land and sea which are fundamental to the traditional ways of life of Inuit hunters in the Arctic, are often poorly recognised in comparison to the predicted material and economic impacts of climate change (Adger et al, 2011). The capabilities approach to justice, the philosophical offspring of developmental economist Amartya Sen and legal philosopher Martha Nussbaum $(2010 ; 2007)$, argues that justice should be defined in terms of human capabilities to do and be different things, and achieve the outcomes which people desire. The ability to secure most, if not all of these 'capabilities' is threatened by climate change; such as the potential effects of climate change on Nussbaum's capability of emotional health for those made into climate refugees (Schlosberg, 2012: 454).

The text of the UNFCCC is testament to the fact that there is no settled definition of climate justice. Its signatories are committed to,

... protect the climate system for the benefit of present and future generations of humankind, on the basis of equity and in accordance with their common but differentiated responsibilities and respective capabilities. (UNFCCC, 1992: article 3(1))

This makes clear that justice is critical to the international climate consensus. However, this sentence contains three different conceptions of justice which might be used to guide climate obligations (equity, causal responsibility and capacity to act), with no guidance as to which is to be prioritised or how the three should be balanced. 


\section{E. Categorising Climate Justice: Conceptual, Pragmatic and Transformative Approaches}

Broadly, three differing accounts of climate justice have been articulated globally (Schlosberg and Collins, 2014: 364). First, academic versions of climate justice tend to focus on ideal notions of justice, adapting theories of social justice to fit the features of climate change. These have led to the creation of several elegant concepts to guide the distribution of the costs of climate change and rights to emit such as 'Contraction and Convergence' (Meyer, 2004) and 'Greenhouse Development Rights' (Baer, 2012). Second, elite NGOs involved in climate discussions - such as the Mary Robinson Foundation for Climate Justice (discussed further below) - are inclined towards a more pragmatic focus on climate policy. They often support the use of market mechanisms to tackle emissions, tend to concentrate their efforts at the global level and advocate human rights based approaches to climate change. At the radical end of the scale, activist versions of climate justice have much in common with the environmental justice movement. Focussing more on the local impacts of climate change, they offer a critique of the dominant capitalist responses to climate change; arguing that alternative economic models are needed to create a just low carbon future (Climate Justice Coalition, 2002; Rising Tide Coalition, 2011). Activist climate justice movements include a range of backgrounds and views, including indigenous peoples, peasant movements, environmentalists, global justice campaigners, trade unionists and scientists (Bullard and Müller, 2012). While there is much variety amongst those who call for climate justice, what they have in common - though to varying extents - is a common belief that the climate status quo is untenable.

We classify these three approaches as being: a) Conceptual b) Pragmatic and c) Transformative - summarised in table 1 below.

\section{***TABLE 1 HERE***}

The following section illustrates how these approaches have been pursued in Scotland and their implications for Scottish climate justice policy and practice.

\section{Climate Justice in Scottish Policy and Practice}

As noted above, to date climate justice has largely been discussed in an international context. The approaches to climate justice outlined in Table 1 are similarly found through discourses 
relating to the international dimensions of climate change. It remains particularly salient to explore the ways in which each of these approaches relate to the domestic context and how they resonate in Scotland. Therefore this section will discuss how each of these approaches has been pursued within Scotland and what the implications might be. The boundaries between the categorisation of the three approaches are non-hermetic - most of the examples discussed display a degree of blurring between categories. This reflects the contested nature of climate justice, which concerns "shades of grey, rather than being black or white" (Sovacool, 2013: 960). The utility of the categorisation is that it provides a method of distinguishing - mainly between transformative and pragmatic approaches to climate justice, as a way of cutting through the questionable rhetoric which often shrouds the latter. As Grear has warned, there is a risk that climate justice may fall victim to "co-option in the service of business as usual" (2014: 104) as it gains institutional acceptance.

\section{A. Conceptual}

Glasgow Caledonian University's Centre for Climate Justice represents the main Scottish example of an institution developing conceptual approaches to climate justice. The centre works in collaboration with the Mary Robinson Foundation for Climate Justice and the Joseph Rowntree Foundation and aims to be "a centre of excellence in climate justice research, teaching and learning" (http://www.gcu.ac.uk/climatejustice/about/visionandgoals/). The centre's activities include the development of a repository of peer-reviewed materials on the socio-economic effects and human-centred implications of climate change, and a range of research projects exploring issues relating to community capacity and resilience to climate change impacts. The focus of the centre's work appears to have been primarily on the international dimensions of climate justice and implications for countries of the global South, however recent collaborations with the Joseph Rowntree Foundation have examined UK dimensions of climate justice (e.g. exploring issues around community resilience), bringing domestic aspects to the fore. Although conceptual in that its work involves the study, promotion and repository of the climate justice discourse - the centre has adopted the MRFCJ approach to climate justice, explicitly committing itself to, "uphold the 'Principles of Climate Justice' created by that body" (http://www.gcu.ac.uk/climatejustice/about/whatisclimatejustice/). As a result - for reasons discussed below - the centre's approach to climate justice exhibits pragmatic - as well as potentially transformative - features. 


\section{B. Pragmatic}

Scottish, and UK, policies relating to climate change have typically taken a pragmatic approach in that mitigation and adaptation are pursued in ways which are non-threatening to modern lifestyles or capitalist systems of production (Aitken, 2012). For example, in setting out Scotland's commitments to taking action on climate change the Scottish Government has stated that its 'clear focus is to increase sustainable economic growth and to raise economic performance, while at the same time reducing our impact on the planet' (Scottish Government, 2010). Thus, despite vocal commitments to sustainable development, economic growth remains a top priority (Ross, 2015). This reflects a position of ecological modernisation whereby environmental problems - such as climate change - are seen as being appropriately addressed through existing modern institutions and structures (Mol and Spaargaren, 2000) rather than requiring new approaches or disruption. This position is modernist in its commitment to economic development and progress through science and technological innovation, exemplified in energy policies which consistently prioritise the development and deployment of new (renewable) technology to meet increasing energy demand over and above measures to improve energy efficiency or reduce energy demand (Aitken, 2012). Within this context it is unsurprising that transformative approaches to addressing climate change typically do not receive significant attention (ibid.) and that those which are adopted by policy-makers typically reflect similarly pragmatic underpinnings - that is they do not represent or suggest fundamental challenges to the status quo.

An example of a pragmatic approach to climate justice currently advanced in Scotland comes through the 2020 Climate Group, now chaired by the former managing director of Lloyds Banking Group Scotland, Lady Susan Rice. The group's mission statement is: "Working together to deliver a low carbon future for Scotland through smarter collaborations and better conversations" and they state that their long term aim is "to contribute to the transformational change required for Scotland to progress to a low carbon economy by bringing together business, voluntary and public sectors to work together" (http://www.2020climategroup.org.uk/about-us/mission/). Whilst transformational change is referred to, the group can be seen to take a pragmatic approach to addressing climate change in their support of existing Scottish Government policies and their focus on working within 
existing institutional structures with "bring[ing] benefits to the Scottish economy" being a stated objective.

\section{Transformative}

Transformative approaches to climate justice contend that climate injustices are a product of current capitalist systems and that climate justice requires large, structural social and economic changes which go beyond pragmatic responses. Scottish examples of organisations advancing transformative approaches to climate justice include Coal Action Scotland (CAS), Friends of the Earth Scotland (FOTES) and Stop Climate Chaos Scotland (SCCS).

CAS is a grassroots organisation which aims to 'challenge the advancement of coal as an energy source' they state that:

We believe that because the use of fossil fuels is inherently destructive, they have no place in our vision of a better world. We stand against social oppression and environmental destruction in all its forms, and as a result also call for an end to capitalism, patriarchy and racism. (http://coalactionscotland.noflag.org.uk)

Their activities go beyond opposing coal mine developments, and extend to highlighting the wider social, environmental and health implications of fossil fuel dependence. Their actions include coordinating opposition to planning applications, direct action (e.g. site occupations) and awareness raising exercises.

FOTES launched an environmental justice campaign in the first year of the Scottish Parliament (Scandrett et al, 2000); encapsulated in their slogan, "no less than a decent environment for all, no more than our fair share of the Earth's resources". Ongoing campaigns against the introduction of hydraulic fracturing ('fracking') in Scotland, seeking amendments to the legal system to provide access to justice in environmental matters, and for a more sustainable Scottish banking industry (Perman, 2014) demonstrate a desire for structural economic and legal changes which go beyond pragmatic approaches. 
SCCS is a coalition of 60 organisations in Scotland including environment, faith ${ }^{1}$ and international development organisations, trade and student unions and community groups. They aim "to ensure that the commitments set out in the Scottish Climate Change Act become a reality" (http://www.stopclimatechaos.org/stop-climate-chaos-scotland). SCCS is the least 'transformative' of our examples. They use climate justice to frame their work in implementing the Climate Change (Scotland) Act 2009, arguing that its aspiration to reduce Scotland's emissions by at least $42 \%$ by 2020 and $80 \%$ by 2050, recognises Scotland's "moral obligation to take action on climate change" (SCCS, 2012: 1). Furthermore, they make explicit their commitment to the international dimension of climate justice, and propose the greater use of aid to support poorer countries to deal with climate adaptation (ibid). As a coalition representing a diverse range of member organisations, some divergence in interpretations of climate justice is inevitable; but SCCS do not call for a transformed, more 'just' economic model, and could be categorised as either transformative or pragmatic.

\section{Human Rights Based Approach to Climate Change}

The classification of three broad approaches to climate justice is useful for evaluating what is currently happening in Scotland and reflecting on the positions underpinning activities or initiatives pursued as climate justice. However, very often in practice approaches to climate justice may not fit neatly or consistently under any one heading. This is exemplified in the dominant approach to climate justice in Scotland: the Human Rights Based Approach (HRBA) to Climate Change. This has been advanced by key actors (most notably the Scottish Human Rights Commission), received broad acceptance in the Scottish Parliament and has been adopted as Scottish Government policy (Scottish Parliamentary Debate on Climate Justice (Stewart Stevenson), 2012; SHRC, 2013).

We describe the HRBA as a predominately pragmatic approach to climate justice; which also displays conceptual and transformative elements. We now explore the ways in which these elements interact and how they have been pursued and prioritised (and/or marginalised) in practice.

\footnotetext{
${ }^{1}$ E.g. the Church of Scotland has been particularly active in the development of the climate justice agenda in Scotland. On the role of churches more generally, see Rathgeber (2012).
} 


\section{A. Background}

The Scottish Parliament motion on climate justice explicitly adopted the language of human rights to frame the debate, and a HRBA to climate change is now consistently presented as being at the heart of climate justice in Scotland (SHRC, 2009). Although no universal template for a HRBA exists, the core of the approach is that the rules, principles, standards and goals of the international human rights system are integrated into the plans and decision-making processes in relation to a certain topic. A HRBA creates an anticipatory (rather than remedial) human rights-compliance model whereby policy-makers anticipate and mitigate human rights problems in the policy development process - ensuring that the resulting policies are fully compliant with human rights rules. This application of the idiom 'prevention is better than cure' is said to help rights to become "less declaratory and more operational" (Gready, 2008: 736). HRBAs have tended to focus on the global development context - but attention is increasingly being turned to other areas such as the protection of migrant workers, protection of religious cultural property, education, food security, health, public space, urban planning, childhood (Tobin, 2011) - and now, climate change.

A HRBA takes a proactive approach in not only preventing breaches of human rights but actively aiming to strengthen and protect human rights through ensuring accountability and participation. Alongside the application of human rights rules, a HRBA also requires that the principles derived from international human rights treaties should guide policies and programming. The 'PANEL' acronym is often used to describe the application of a HRBA (Vandenhole and Gready, 2014: 294), requiring that it contains the following features: (i) Participation - whereby people are recognised as actors in policy development and implementation, and their free and informed participation is encouraged; (ii) Accountability practices and mechanisms are developed to ensure that human rights entitlements are met and that violations can be addressed; (iii) Non-discrimination - a focus is placed on traditionally marginalised and disadvantaged groups; (iv) Empowerment - people are encouraged to actively claim their rights, and hold duty bearers to account for their realisation; (v) Linkages (or 'legality') - policy is linked to human rights standards, ensuring that policy is developed and implemented in a human rights-friendly manner.

There is no universal definition of a HRBA and the PANEL acronym is no more than a rough blueprint. On the one hand, this provides those charged with its implementation with considerable freedom in applying the approach, and adapting it to the circumstances of their 
particular topic. Yet on the other, a HRBA is often phrased at such a level of abstraction that it is uninformative as to its application - for example the call to apply the human rights principle of 'participation'. As Sherry Arnstein famously explained, the notion of 'participation' is capable of a range of interpretations - such as when the rhetoric of participation is cynically harnessed to legitimise elite decision-making (1969).

\section{B. HRBA as a conceptual approach}

A HRBA to climate change can be viewed as a conceptual approach to climate justice in that it applies existing human rights principles to climate change. In doing so it links previously disconnected topics, creating novel challenges and dilemmas. It provides a new theoretical lens through which to view the challenges and impacts of climate change whilst also opening up new debates around rights and responsibilities associated with climate change mitigation and adaptation policies.

A HRBA is described as a mechanism for putting people at the heart of climate change (Oxfam, 2008). It recognises that various human rights are threatened by the impacts of climate change as well as through the implementation of mitigation and adaptation policies - and seeks to ensure that climate policy complies with human rights standards (Humphreys, 2010; LeónMoreta, 2011). Rights affected by climate change include the right to life (deaths, diseases and injury resulting from extreme weather events); the rights to food and water (changing weather patterns affecting land-use, water shortages and food production); the right to an adequate standard of living (displacement/migration, water shortages and impacts on biodiversity) and the right to health (projected increases in water and vector-borne diseases and malnutrition) (Oxfam, 2008, SHRC, 2009).

However, whilst a HRBA may be conceptual in origin it is being operationalised in practical and policy-orientated ways with - potentially - both pragmatic and transformative implications.

\section{HRBA as a pragmatic approach}

We posit that a HRBA, as currently pursued, should be considered as a mainly pragmatic approach since it largely relies on existing structures and institutions to promote climate justice 
rather than challenging these systems. Several aspects of the HRBA can be highlighted to illustrate some of its pragmatic features.

First, a HRBA to climate change focusses on the effects of climate change, rather than its causes. Scotland's enthusiastic application of what could be described as the, 'Mary Robinson Foundation Formula for Climate Justice': climate change strategy + human rights = climate justice (Franks, 2013: 178), neglects the history of climate change causation (one for which Scotland bears a heavy historical responsibility as an early industrialiser). This could be viewed as an attempt to paint Scottish climate policy with an ethical human rights gloss, neglecting the historical undercoat needed to prepare Scotland for a just transition. In addition, a HRBA to climate change may not lead to the large structural, social and economic changes envisaged by those who call for a transformative approach to climate justice. It is unclear whether the vested interests behind climate injustice, such as fossil fuel corporations (of whom Scotland is home to a disproportionate number), will be directly affected by a HRBA; or whether a HRBA would lead to more public participation in economic decision making.

Second, there is perhaps a fundamental mismatch between the need for effective climate action and a HRBA. Climate change is a 'collective action problem' (Ostrom, 2010) - all nations face the possibility of extremely adverse outcomes that could be reduced if many participants take expensive actions. Human rights on the other hand, represent a system designed for the protection of the dignity of the individual, providing obvious potential for conflict between collective and individual goals. The dominant global interpretation of the right to development as based upon an environmental resource-dependant, infinite growth model also conflicts with understanding on planetary boundaries (Natarajan, 2015). Furthermore, human rights carry an 'anthropocentric' assumption about humanity's dominant role in the world which some argue is the root of environmental degradation (Eckersley, 1992: 49-55; Cullinan, 2011: 104-109).

Third, the success of a HRBA is dependent upon a vibrant 'human rights culture'. Under such conditions, citizens, civil society and public authorities are informed of and actively protective of rights. This is currently lacking in Scotland. The lack of education and awareness of rights in Scotland (SHRC, 2013: 30), combined with the consistently negative, and often dishonestly inaccurate portrayal of human rights by the UK media and political elites (Wagner, 2014) militate against the development of a Scottish human rights culture. This is compounded by a lack of enforceable socio-economic rights in Scotland due to the UK's failure to incorporate 
treaties such as the International Covenant on Economic, Social and Cultural Rights 1966 into the domestic legal order.

Fourth, it may be criticised as a way of empowering those well-versed in the language of human rights, particularly lawyers. Koskenniemi has argued that HRBAs represent a hegemonic project for seizing power (2010), allowing those in the human rights field to seize more influence over public policy, further entrenching the power of lawyers and litigative methods at the expense of other policy actors and approaches. Koskenniemi's claim has merit, but is somewhat exaggerated. The language and adjudication of human rights claims is primarily legal; however, a HRBA implies increased public participation in the formation of policy from civil society, not just lawyers. Furthermore, the preventative nature of a HRBA, which 'frontloads' public policy to avoid human rights compliance issues arising in the implementation stage could result in less litigation.

\section{HRBA as a transformative approach}

Despite the limitations of a HRBA, it retains a transformative potential. This is clear within the HRBA's calls for participation and accountability in decision-making and policy implementation. Through an emphasis on empowering people to participate in policy and increasing accountability of policy-makers, a HRBA suggests greater democratisation within climate change policy-making and implementation.

Previous work on a HRBA to development has pointed to its transformative potential, giving "the promise of re-politicising areas of development work - particularly, perhaps, efforts to enhance participation in development - that have become domesticated as they have been mainstreamed by powerful institutions like the World Bank" (Nyamu-Musembi \& Cornwall, 2004: 1). HRBAs are inherently political in calling for greater equity and increased agency of rights-holders.

As discussed above - climate change has been de-politicised. A HRBA can help to reinvigorate climate politics by shifting the motivation for climate interventions from one dictated by benevolence to climate victims, a narrow economic logic which assesses climate action through a cost-benefit lens or in terms of potential security threats to strategic national interests; to a richer appreciation of the risks to the enjoyment of universal, fundamental human entitlements and ultimately, dignity. The use of 'rights talk' can strengthen the marginalised, and could help 
to inspire and mobilise those who have otherwise been silenced in climate debates (ibid). Human rights provide useful guiding principles that can be used to direct and appraise policy, building a new climate politics which accommodates those suffering the worst impacts (Nicholson and Chong, 2011). However, in practice, experience with HRBAs in other policy spheres has demonstrated that the necessary changes in long-established, and well-entrenched power relations are not easily realised (Nyamu-Musembi \& Cornwall, 2004).

Moreover, a HRBA calls for participation and accountability in decision-making and implementation of climate change policies. They seek to 'empower people themselves (rightsholders) - especially the most marginalized - to participate in policy formulation and hold accountable those who have a duty to act (duty-bearers)' (OHCHR, n.d.). This relationship between 'duty bearers' (actors with obligations to respect, protect and fulfil rights) and 'rights holders' (individuals/groups with rights claims), can empower rights-holders to hold dutybearers to account for the fulfilment of human rights entitlements. The power of a HRBA to hold duty-bearers to account applies at a variety of levels, domestically and internationally, legally and otherwise (Rajamani, 2010: 417-419). However, the strength of this relationship between duty-bearers and rights-holders depends upon the existence of and conditions of access to appropriate mechanisms to secure accountability of duty bearers (such as courts), supportive institutions (such as the SHRC and the various UN-level human rights institutions) and a degree of awareness amongst rights-holders.

This points to potential areas of learning for a HRBA to climate justice. There are transformative elements implicit within this approach in terms of additional participation and accountability requirements, the provision of a strong moral call for action on climate change and a useful metric to assess climate policies. However, the realisation of the transformative potential of a HRBA depends on how a HRBA is pursued and the commitments of institutions or policy-actors to promote a greater democratisation of climate policy, which is by no means certain.

\section{HRBA - conceptual, pragmatic or transformative?}

Evidently a HRBA to climate change is not clearly defined, and there may be many methods of implementation. A HRBA has considerable value in providing a new conceptual framework through which to explore issues and challenges associated with climate change and in developing justice-centred approaches to climate change. In more practical terms a HRBA 
offers great potential but is also fraught with challenges and potential shortfalls. Notably, the extent to which a HRBA can realise its transformative potential and lead to greater democratisation in climate change policy-making and implementation depends on the willingness and commitment of institutions facilitating such processes. Whilst a HRBA implies empowering rights-holders through greater participation and increased accountability of policy institutions, in practice if such power is not meaningfully devolved a HRBA can instead further entrench long-established power relations and strengthen the hegemony of dominant actors. The pragmatic nature of a HRBA in working with - rather than challenging - existing systems and structures may be important for bringing about the success that such approaches have had in entering mainstream policy discourse but can also be seen as a potential obstruction to the realisation of their transformative potential.

\section{Conclusions: What does Climate Justice mean in Scotland?}

With an increasing understanding of the causes and effects of climate change, and the implications of mitigation and adaptation strategies, the demand for a just transition to a low carbon society has grown. This has manifested in Scotland with a firm policy commitment to the pursuit of 'climate justice' being made in 2012. This commitment might be seen as a bold gesture bringing a previously alternative framing of climate change discourse into the mainstream policy arena, however it also draws attention to the flexibility and ambiguity in how 'climate justice' is understood and pursued.

The classification of three approaches to climate justice provides a useful analytical tool for exploring the different forms that climate justice can take and the various underpinnings that these have (whether implicit or explicit). As our analysis has demonstrated, in practice approaches to climate justice are unlikely to neatly fit under one heading - the boundaries between conceptual, pragmatic and transformative approaches are likely to always be somewhat blurry. However, exploring the conceptual, pragmatic and transformative elements of climate justice in policy and practice offers a way of revealing the different positions and their relative impact on policy in Scotland.

Climate justice is a label which is applied to a range of practices in Scotland, with differing results. Our classification highlights different positions and their policy implications and has demonstrated that pragmatic approaches are the most readily adopted; whereas transformative 
approaches remain on the fringes of climate policy debates. This is perhaps unsurprising given that pragmatic approaches are largely uncritical of existing political and institutional structures whereas transformative approaches suggest more radical changes to the status quo. Pragmatic approaches bring the benefits of greater influence in mainstream policy-making, but can represent a form of low-carbon business as usual - a questionable use of the climate justice label. Their dominance means that the transformative potential of climate justice may not be realised, and it may become a rhetorical device used to entrench pragmatic approaches.

This threatens the transformative potential of a climate justice agenda in Scotland. A HRBA has the potential to re-orientate and repoliticise the climate debate - providing an ethical yardstick against which to measure and aim climate policies at home and internationally. However, a HRBA may be implemented in pragmatic as well as transformative ways. Criticisms relate to its forward-looking nature, neglecting the history of the climate problem; representing an anthropocentric and individualist agenda which may be at odds with effective climate solutions, being dependent upon a hitherto non-existent healthy Scottish 'human rights culture' and carrying risks of strengthening powerful sections of society (particularly the legal profession). Nevertheless, with meaningful individual, institutional and political commitments, a HRBA would have significant transformative potential - with top-down support for a HRBA the grassroots of climate justice could flourish in Scotland.

It is hoped that this article enlightens readers as to the variety of potential climate justice ingredients available, encourages further reflection and debate on the particular flavour of climate justice which has been chosen in Scotland and the implications of our somewhat limited menu.

\section{References}

Adger, N.; Barnett, J.; Chapin, F.; Ellemor, H. (2011). This must be the place: underrepresentation of identity and meaning in climate change decision-making. Environmental Politics, vol. 11(2), 1-25.

Agyeman, J. (2002). Constructing Environmental (in)justice: transatlantic tales. Environmental Politics, vol. 11(3), 31-53.

Aitken, M. (2012). Changing climate, changing democracy: a cautionary tale. Environmental Politics, vol. 21(2), 211-229.

Arnstein, S. (1969). A ladder of citizen participation. Journal of the American Institute of Planners, vol. 35, 216-24 
Baer, P. (2012). The greenhouse development rights framework for global burden sharing: reflection on principles and prospects. Wiley Interdisciplinary Reviews: Climate Change, vol. 4(1), 61-71.

BBC News (2007). Billions face climate change risk. http://news.bbc.co.uk/1/hi/6532323.stm. [Accessed 20 February 2015]

Benford, R. (2005). The Half-Life of the Environmental Justice Frame: Innovation, Diffusion, and Stagnation. In D. Pellow and R. Brulle (eds.), Power, Justice and Environment: A Critical Appraisal of the Environmental Justice Movement, 37-54. Cambridge: MIT Press.

Bond, P. (2012). Politics of Climate Justice: Paralysis Above, Movement Below. Scottsville: University of KwaZulu-Natal Press.

Bullard, R. D. (1993). 'Race and environmental justice in the United States'. Yale Journal of International Law, 18: 319.

Bullard, R. (2000). Environmental Justice in the Twenty-first Century. In R. Bullard (ed.) The Quest for Environmental Justice: Human Rights and the Politics of Pollution, 19-42. Oakland, CA: University of California Press.

Bullard, N., \& Müller, T. (2012). 'Beyond the 'Green Economy': System change, not climate change \& quest'. Development, vol. 55(1): 54-62.

Burnham, M.; Radel, C.; Ma, Z. and Laudati, A. (2013). Extending a geographic lens towards climate justice, part 1: climate change characterization and impacts. Geography Compass, vol. 7(3), 239-248.

Chatterton, P.; Featherstone, D. and Routledge, P. (2013). Articulating Climate Justice in Copenhagen: Antagonism, the Commons, and Solidarity. Antipode, vol. 45(3), 602-620.

Climate Justice Coalition (2002). Bali Principles of Climate Justice. http://www.ejnet.org/ej/bali.pdf. [Accessed 20 February 2015]

Committee on Climate Change. (2014). Energy prices and bills - impacts of meeting carbon budgets. London: CCC.

Cullinan, C. (2011). Wild Law: A Manifesto for Earth Justice. Totnes: Green Books, second edition.

Eckersley, R. (1992). Environmentalism and Political Theory: Toward an Ecocentric Approach. London: UCL Press.

Evans, G. (2010). 'A rising tide: Linking local and global climate justice'. Journal of Australian Political Economy, vol. 66(11): 199-221.

Franks, A. (2013) Making relations and performing politics: an ethnographic study of climate justice in Scotland with So We Stand. Glasgow: University of Glasgow.

Friends of the Earth. (1999). Pollution Injustice: the geographic relation between household income and polluting factories. London: Friends of the Earth.

Gough, I. (2011). Climate Change, Double Injustice and Social Policy: A Case Study of the United Kingdom. Geneva: UN Research Institute for Social Development. 
Gready, P. (2008). Rights-based approaches to development: what is the value-added? Development in Practice, vol. 18(6), 735-747.

Grear, A. (2014). Towards 'climate justice'? A critical reflection on legal subjectivity and climate injustice: warning signals, patterned hierarchies, directions for future law and policy. Journal of Human Rights and the Environment, vol. 5(0), 103-133.

Hodson, M. and Marvin, S. (2013). Low Carbon Nation? Oxford: Routledge.

Honneth, A. (2004). Recognition and justice: outline of a plural theory of justice. Acta Sociologica, vol. 47(4), 351.

Humphreys, S. (ed.) (2010). Human Rights and Climate Change. Cambridge: Cambridge University Press.

Jamieson, D. (2010). Climate change, responsibility, and justice. Science and Engineering Ethics, vol. 16(3), 431-45.

Karliner, J. (2000). Climate Justice Summit Provides Alternative Vision. http://www.corpwatch.org/article.php?id=977. [Accessed 20 February 2015]

Kohn, M. (2010). Turned Out Nice: How the British Isles will Change as the World Heats Up. London: Faber and Faber.

Koskenniemi, M. (2010). Human rights mainstreaming as a strategy for institutional power. Humanity: An International Journal of Human Rights, Humanitarianism, and Development, vol. 1(1), 47.

Lee, M.; Armeni, C.; de Cendra, J.; Chaytor, S.; Lock, S., Maslin, M.; Redgwell, C.; and Rydin, Y. (2013). Public participation and climate change infrastructure. Journal of Environmental Law, vol. 25(1), 33-62.

León-Moreta, M. (2011). Biofuels - a threat to the environment and human rights? an analysis of the impact of the production of feedstock for agrofuels on the rights to water, land and food. European Journal of Legal Studies, vol. 4(1) 102-120.

Liverman, D. (2009). Conventions on climate change: constructions of danger and the dispossession of the atmosphere. Journal of Historical Geography, vol. 35(2), 279-296.

Low, N. and Gleeson, B. (1998). Justice, Society and Nature: An Exploration of Political Ecology. London: Routledge.

Mary Robinson Foundation - Climate Justice (MRFCJ) (2012). Scottish Parliament passes motion on climate justice. http://www.mrfcj.org/news/scottish-parliament-passes-motion-onclimate-justice.html. [Accessed 20 February 2015]

Mary Robinson Foundation - Climate Justice (MRFCJ) (2013) Climate Justice Baseline. http://www.mrfcj.org/media/pdf/ClimateJusticeBaseline.pdf. [Accessed 20 February 2015]

Meyer, A. (2004). Briefing: contraction and convergence. Engineering Sustainability, vol. 157(4), 189-192. 
Mol, A. P. J. and Spaargaren, G. (2000). 'Ecological modernisation theory in debate: a review' In: A. P. J. Mol and D. A. Sonnenfeld (eds.). Ecological modernisation around the world: perspectives and critical debates, 17-49. London: Frank Cass.

Mueller, T., \& Bullard, N. (2012). 'Beyond the "Green Economy": System Change, Not Climate Change?' Development, 55(1): 54-62.

Natarajun, U. (2015). Human rights - help or hindrance to combatting climate change? https://www.opendemocracy.net/openglobalrights-blog/usha-natarajan/human-rights\%E2\%80\%93-help-or-hindrance-to-combatting-climate-change. [Accessed 20 February 2015]

Newell, P. and Paterson, M. (2010). The Politics of the Carbon Economy. In M. Boykoff (ed.), The Politics of Climate Change: A Survey, 77-95. London: Routledge.

Nicholson, S. and Chong, D. (2011). Jumping on the human rights bandwagon: how rightsbased linkages can refocus climate politics. Global Environmental Politics, vol. 11(3), 121136.

Nyamu-Musembi, C. and Cornwall, A, 2004, 'What is the Rights-based Approach all about? Perspectives from International Development Agencies', IDS Working Paper no. 234, Institute for Development Studies, Brighton.

Nussbaum, M. (2007). Frontiers of Justice: Disability, Nationality, Species Membership. Cambridge MA: Harvard University Press.

Office of the High Commissioner for Human Rights (n.d.), Applying a Human Rights-Based Approach to Climate Change Negotiations, Policies and Measures http://www.ohchr.org/Documents/Issues/ClimateChange/InfoNoteHRBA.pdf. [Accessed 20 February 2015]

Ostrom, E. (2010). Polycentric systems for coping with collective action and global environmental change. Global Environmental Change, vol. 20(4), 550-557.

Oxfam. (2008). Climate Wrongs and Human Rights: Putting People at the Heart of Climate Change Policy. Oxford: Oxfam International.

Pedersen, O. (2014). What happened to environmental justice? Environmental Law Review, vol. 16(2), 87-90.

Perman, R. (2014). Smaller, Greener Banking: Banking for Sustainability in a New Scotland. Edinburgh: FOTES.

Posner, E. and Weisbach, D. (2010). Climate Change Justice. Princeton: Princeton University Press.

Preston, I.; White, V.; Thumim, J.; Bridgeman, T. and Brand, C. (2013a). Distribution of Carbon Emissions in the UK: Implications for Domestic Energy Policy. York: Joseph Rowntree Foundation.

Preston, I.; White, V.; Croft, D.; and Sturtevant, E. (2013b). The hardest hit: Going beyond the mean. London: Consumer Futures. 
Preston, I.; Banks, N.; Hargreaves, K.; Kazmierczak, A.; Lucas, K.; Mayne, R.; Downing, C. and Street, R. (2014). Climate Change and Social Justice: An Evidence Review. York: Joseph Rowntree Foundation.

Rajamani, L. (2010). The increasing currency and relevance of rights-based perspectives in the international negotiations on climate change. Journal of Environmental Law, vol. 22(3), 391429.

Rathgeber, T. (2012). Climate Justice, Human Rights and the Role of the Churches. Geneva: World Council of Churches.

Rising Tide Coalition for Climate Justice (2011), The Rising Tide Coalition for Climate Justice Political Statement. http://risingtide.org.uk/about/political. [Accessed 20 February 2015]

Ross, A. (2015). The future Scotland wants - is it really all about Sustainable Economic Growth? The Edinburgh Law Review, vol. 19(1), 66-100.

Sachs, W. and Santarius, T. (2007). Fair Future: Resource Conflicts, Security, and Global Justice. London: Zed Books.

Scandrett, E. (2007). Environmental justice in Scotland: policy, pedagogy and praxis. Environmental Research Letters, vol. 2(4), 045002.

Scandrett, E.; Dunion, K. and McBride, G. (2000). The Campaign for Environmental Justice in Scotland. Local Environment, vol. 5(4), 467-474.

SCCS (2012), SCCS Briefing on climate justice. SCCS. http://www.stopclimatechaos.org/sites/default/files/sccs-briefing-climate-justice-final_2.pdf.

[Accessed 20 February 2015]

Schlosberg, D. (2007). Defining Environmental Justice: Theories, Movements and Nature. Oxford: Oxford University Press.

Schlosberg, D. (2012). Climate justice and capabilities: a framework for adaptation policy. Ethics and International Affairs, vol. 26(4), 445-461.

Schlosberg, D. (2013). Theorising environmental justice: the expanding sphere of a discourse. Environmental Politics, vol. 22(1), 37-55.

Schlosberg, D. and Collins, L. (2014). From environmental to climate justice: climate change and the discourse of environmental justice. Wiley Interdisciplinary Reviews: Climate Change, vol. 5(3), 359-374.

Scottish Government. (2009). Climate Change Delivery Plan: Meeting Scotland's statutory climate change targets http://www.scotland.gov.uk/Resource/Doc/276273/0082934.pdf. [Accessed 20 February 2015]

Scottish Government, (2010). Towards a Low Carbon Economy for Scotland: Discussion Paper http://www.gov.scot/Publications/2010/03/22110408/0. [Accessed 20 February 2015]

Scottish Government, (2014), Scottish Climate Justice Fund Round Two http://www.scotland.gov.uk/Resource/0044/00448275.pdf. [Accessed 20 February 2015]

Sen, A. (2010). The Idea of Justice. London: Penguin. 
SHRC, 2009, Human Rights and Climate Change: A joint Communiqué Between The Scottish Government, the Scottish Human Rights Commission, the Scottish Environment Protection Agency and BTCV Scotland www.scottishhumanrights.com

SHRC (2013). Scotland's National Action Plan for Human Rights: 2013 - 2017. Edinburgh: SHRC.

Singer, P. (2010). One Atmosphere. In S. Gardiner; S. Caney; D. Jamieson and H. Shue (eds.), Climate Ethics: Essential Readings, 182-199. Oxford: Oxford University Press.

Sovacool, B. (2013). The complexity of climate justice. Nature Climate Change, vol. 3(11), 959-960.

Swyngedouw, E. (2010). Apocalypse forever? Post-political populism and the spectre of climate change. Theory, Culture and Society, 27 (2-3): 213-232

Terry, G. (2009). No climate justice without gender justice: an overview of the issues. Gender and Development, vol. 17(1), 5-18.

Tobin, J. (2011). Understanding a Human Rights Based Approach to Matters Involving Children: Conceptual Foundations and Strategic Considerations. In A. Invernizzi and J. Williams (eds.), The Human Rights of Children: From Visions to Implementation, 61-98. London: Ashgate.

UK Government (2012). UK Climate Change Risk Assessment: Government Report. London: HMSO.

United Nations Framework Convention on Climate Change (UNFCCC), (1992). http://www.unfccc.int. [Accessed 20 February 2015]

Van der Horst, D. (2014). Climate policy and the siting of renewable energy projects: towards common but differentiated responsibility at the community level. People, Place and Policy, vol. 8(3), 222-234.

Vandenhole, W. and Gready, P. (2014). Failures and Successes of Human Rights-Based Approaches to Development: Towards a Change Perspective. Nordic Journal of Human Rights, vol. 32(4), 291-311.

Wagner, A. (2014). The Monstering of Human Rights. Presentation at the Conference on Human Rights in the UK Media: Representation and Reality, University of Liverpool. https://adam1cor.files.wordpress.com/2014/09/the-monstering-of-human-rights-adamwagner-2014.pdf. [Accessed 20 February 2015]

Walker, G. (2009). Globalizing environmental justice: the geography and politics of frame contestation and evolution. Global Social Policy, vol. 9(3), 355-382.

Weiss, E. (1989). In Fairness to Future Generations: International Law, Common Patrimony, and Intergenerational Equity. Tokyo: United Nations Publishers. 
Table 1: Approaches to Climate Justice ${ }^{2}$

\begin{tabular}{|c|c|c|c|}
\hline & Rationale & Features & Examples \\
\hline Conceptual & $\begin{array}{l}\text { Adapting notions of } \\
\text { justice to features of } \\
\text { climate change. }\end{array}$ & $\begin{array}{ll}\text { - } & \text { Idealist. } \\
\text { - } & \text { Abstract/theoretical. } \\
\text { - } & \text { Often explicitly } \\
& \text { based on theories of } \\
& \text { social justice. } \\
\text { - } & \text { Sources - } \\
\text { academia, 'think- } \\
\text { tanks', NGOs. }\end{array}$ & $\begin{array}{l}\text { - Contraction and } \\
\text { Convergence. } \\
\text { - Greenhouse } \\
\text { Development Rights. } \\
\text { - Glasgow Caledonian } \\
\text { University Centre for } \\
\text { Climate Justice. }\end{array}$ \\
\hline Pragmatic & $\begin{array}{l}\text { Pursuing climate } \\
\text { justice through } \\
\text { existing economic } \\
\text { frameworks and } \\
\text { policy mechanisms: } \\
\text { 'climate capitalism'. }\end{array}$ & $\begin{array}{l}\text { Use established } \\
\text { policy mechanisms } \\
\text { - market tools, } \\
\text { human rights. } \\
\text { - Climate justice } \\
\text { requires a } \\
\text { decarbonised } \\
\text { economy, but } \\
\text { further structural } \\
\text { alterations are } \\
\text { unnecessary. } \\
\text { - Tend to focus on } \\
\text { the global scale. } \\
\text { - Focus on the ends, } \\
\text { not the means. } \\
\text { - Sources - policy } \\
\text { documents, larger } \\
\text { NGOs. }\end{array}$ & $\begin{array}{l}\text { - EU Emissions Trading } \\
\text { Scheme. } \\
\text { - Climate Action } \\
\text { Network. } \\
\text { - Mary Robinson } \\
\text { Foundation - Climate } \\
\text { Justice. }\end{array}$ \\
\hline Transformative & $\begin{array}{l}\text { Providing a critique of } \\
\text { dominant capitalist } \\
\text { responses to climate } \\
\text { change; arguing that } \\
\text { alternative economic } \\
\text { models are needed to } \\
\text { create a just low } \\
\text { carbon society. }\end{array}$ & $\begin{array}{l}\text { Critical of existing } \\
\text { climate policies - } \\
\text { often anti- } \\
\text { globalisation: } \\
\text { 'system change, not } \\
\text { climate change'. } \\
\text { - Advocate radical } \\
\text { action in the short- } \\
\text { term: 'leave the oil } \\
\text { in the soil, coal in } \\
\text { the hole, the tar } \\
\text { sand in the land, } \\
\text { and the shale gas } \\
\text { under the grass'. } \\
\text { - Often more local in } \\
\text { scale. } \\
\text { - Views climate } \\
\text { change as a } \\
\text { symptom of wider }\end{array}$ & $\begin{array}{l}\text { - Climate Justice Now! } \\
\text { - Bali Principles of } \\
\text { Climate Justice. } \\
\text { - People's Agreement } \\
\text { of Cochabamba. } \\
\text { - Coal Action Scotland. } \\
\text { - Friends of the Earth } \\
\text { - Scotland. } \\
\text { - Stop Climate Chaos } \\
\text { Scotland. } \\
\text { - 360.org (Bill } \\
\text { McKibben and Naomi } \\
\text { Klein). }\end{array}$ \\
\hline
\end{tabular}

\footnotetext{
${ }^{2}$ Developed from Schlosberg and Collins (2014).
} 


\begin{tabular}{|l|l|l|}
\hline & economic ills: large, \\
& structural \\
social/economic & \\
changes are needed & \\
- beyond pragmatic & responses. \\
& - Rejection of \\
& technocratic \\
& responses to climate \\
change - such as & geo-engineering. \\
& - Sources - smaller \\
& activist groups, \\
& citizen movements, \\
smaller NGOs. & \\
&
\end{tabular}

